一論 文—

（日本化学会誌，1988，（3），p.321 325）

(C) 1988 The Chemical Society of Japan

\title{
単環式および二環式モノテルペンオキシド類の 無機混合溶融塩による熱分解反応122)
}

(1987 年 8 月 26 日 受理)

\author{
野 村 正 人*・藤 原 義 人
}

\begin{abstract}
単環式および二環式モノテルペンオキシド類について硝酸塩系溶融塩 $\left(\mathrm{NaNO}_{2} / \mathrm{NaNO}_{3} / \mathrm{KNO}_{8}\right)$ およ び塩化物系溶融塩 $\left(\mathrm{ZnCl}_{2} / \mathrm{KCl} / \mathrm{NaCl}\right)$ 中での熱分解反応を行ない, 2 種の無機混合溶融塩の相違と反 応温度との関係について検討するとともに，反応生成物の選択性についても検討した。

その結果, 塩化物系溶融塩を用いた場合, trans-リモネン-1,2-オキシド[1]からは反応温度 $310^{\circ} \mathrm{C}$ の条件下に扰いてネオ扰びイソジヒドロカルボン [7]，[8]の 2 成分 $(2: 3)$ のみが得られる最道 条件を見いだすことができた。1,2-エポキシ-4-p-メンテン〔3]からは反応温度 $200^{\circ} \mathrm{C}$ の条件下にお いて 4-p-メンテン-2-オン [17] が 77\% の生成比を占めた。2-ピネンオキシド [4] からは $\alpha$-カン ホレンアルデヒド [18]とピノカルボン [19]の 2 成分を生成物中, 最高 $97 \%$ の生成比で得ること ができた。また，2(10)-ピネンオキシド〔5]からはいずれの溶融塩においてもミルタナール[21]が 主成分として得られることが判明した。
\end{abstract}

\section{1 緒言}

従来，テルペノイドの異性化，熱分解反応は常圧下，高温で活 性白土,シリカゲルなどを触媒として行なわれている314。これら の反応では反応系における反応熱のため反応温度の維持などに困 難をきたしていると同時に, 反応の選択性あるいは触媒の活性保 持などにいまだかなり多くの課題が残されている。また，溶融 塩を有機反応の触媒として利用した研究例はあまり見あたらな (.5)。

そこで，最近著者らは熱效率がよく，触媒劣化に腐心する必要 のない熱媒体である $\mathrm{NaNO}_{2} / \mathrm{NaNO}_{3} / \mathrm{KNO}_{3}$ (以下, 硝酸塩系溶融 塩之略記する) と, $\mathrm{ZnCl}_{2} / \mathrm{KCl} / \mathrm{NaCl}$ (以下，塩化物系溶融塩と略 記する) の 3 元素系混合溶蛅塩を調製しここれら両系溶融塩を用 いて数種のテルペン峞化水素の異性化的ならびにテルペニルアセ タート類の熱分解反応 ${ }^{788}$ について検討した。その結果, これら数 種のテルペノイドの溶融塩存在下での反応は硝酸塩系溶融塩に拉 いては比較的高い反応温度で反応が進行するなどの点から熱媒体 としての役割りが，一方，塩化物系溶融塩に掠いては触媒的な役 制りがあることが考穴られ，従来の異性化法早101などにくらべて

近戴大学工学部工業化学科, 737-01 吳市広古新開

1）この報文を “テルペン類の溶融塩を用いる反応関する研 究（第 6 報）”とする.

2）前報(第 5 報)，野村正人，藤原義人， 日化，1984，611.

3）岡田幸雄, 伏崎你三郎, 工化, 59, 719(1956).

4) B. D. Sully, Chem. Ind., 1964, 263.

5) D. B. Fox, E. H. Lee, CHEMTECH., 1973, 186.

6）野村正人, 藤原義人, 松原義治, 油化学, 28, 919(1979).

7）野村正人，藤原義人，松原義治，日化，1979，1282.

8）野村正人，藤原義人，日化，1984，611.

9) A. B. Booth, E. A. Klein, U. S. P., 2, 803, 659(1957).
も有用なテルベノイドが選択率よく得られるなど良好な結果を見 いだすことができた。また，触媒としての活性低下などに腐心す る必要がなく，この手法がテルペノイドの連続熱異性化，あるい は熱分解法として有利な反応であることを報告78)した。

今回，本報では上記関連研究の一環として，いまだ，試みられ たことのない単環式扰よび二環式モノテルベンオキシドである trans-リモネン-1, 2-オキシド[1], 1,2-エボキシ-3-p-メンテン [2]，1，2-エボキシ-4-p-メンテン[3]，2-ピネンオキシド[4] および 2(10)-ピネンオキシド〔5]など 5 種類の化合物につい て，さき調製した組成の異なる 2 種類の無機混合容融塩中下吹 き込んで反応を行ない，反応の選択性と反応生成物の検索を行な ったので報告する。

\section{2 実倹}

\section{1 試菜の調製}

trans-リモネン-1, 2-オキシド[1], 1,2-エボキシ-3-p-インテ ン〔 [2]，1，2-エポキシ-4-p-メンテン〔3]，2-ビネンオキシド [4]扰よ゙2(10)-ビネンオキシド[5]; 市眅品 (安原油脂工莱 製) $d$-リモネン, 1, 3-p-メンタジンン, 1, 4-p-メンタジンン, 2-ビ

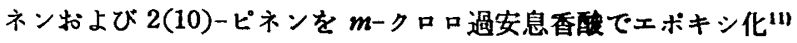
し, 窒素気流下て減压蒸留したものを用いた。その物理定数はつ ぎのと㧍りである。

[1] bp $113 \sim 114^{\circ} \mathrm{C} / 50 \mathrm{mmHg}, n_{\mathrm{D}}^{20}=1.4702, d_{4}^{20}=0.9236$, $[\alpha]_{\mathrm{D}}^{30}=+69^{\circ}$ (neat) (文嗝値 ${ }^{12}$, bp $78.5 \sim 80.5^{\circ} \mathrm{C} / 10 \mathrm{mmHg}$, $n_{\mathrm{D}}^{26}=1.4661,[\alpha]_{\mathrm{D}}=+97.5^{\circ}$ (neat))

10) A. Kergomard, Bull. Soc. Chim. Fr., 1958, 397, 1175.

11) R. M. Bowman, A. Chambers, W. R. Jackson, J. Chem. Soc., 1966, 612. 
(2) bp $86 \sim 88 \mathrm{C} / 10 \mathrm{mmHg}, \quad n_{\mathrm{D}}^{20}=1.4721, \quad d_{4}^{20}=0.9678$

[3] bp $78 \sim 80^{\circ} \mathrm{C} / 5 \mathrm{mmHg}, \quad n_{\mathrm{D}}^{30}=1.4762, \quad d_{4}^{30}=0.9587$

[4] bp $102 \sim 104^{\circ} \mathrm{C} / 50 \mathrm{mmHg}, n_{\mathrm{D}}^{20}=1.4788, d_{1}^{20}=0.9762$, $[\alpha]_{\mathrm{D}}^{20}=-64^{\circ}$ (neat) (文献値 ${ }^{13)}$, bp $102 \sim 103^{\circ} \mathrm{C} / 50 \mathrm{mmHg}, d_{16}$ $\left.=0.9689, n_{\mathrm{B}}^{1}=1.4708,[\alpha]_{\mathrm{D}}=-92^{\circ}\right)$

[5] bp $97 \sim 99^{\circ} \mathrm{C} / 25 \mathrm{mmHg}, \quad n_{\mathrm{D}}^{20}=1.4769, \quad d_{4}^{20}=0.9768$, $[\alpha]_{\mathrm{D}}^{30}=+8.4^{\circ}$ (neat) (文献值 ${ }^{14}$ ), bp $98 \sim 99^{\circ} \mathrm{C} / 33 \mathrm{mmHg}, d_{4}^{21}$ $\left.=0.963, n_{\mathrm{D}}^{31}=1.4756,[\alpha]_{\mathrm{D}}^{16}=+2.9^{\circ}\right)$

\section{2 实雅方法}

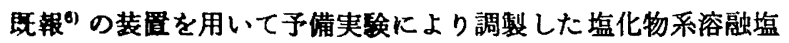
$\left[\mathrm{ZnCl}_{2} / \mathrm{KCl} / \mathrm{NaCl}=75: 14: 11(\mathrm{wt} \%)\right]$ と硝酸塩系溶融塩 $[\mathrm{Na}$. $\left.\mathrm{NO}_{2} / \mathrm{NaNO}_{2} / \mathrm{KNO}_{3}=40: 7: 53(\mathrm{wt} \%)\right]$ をそれぞれ約 $1 \mathrm{~kg}$ を 用いて既埌 ${ }^{61}$ と同様な操作により各試料 [1]〜[5]を所定の条 件下で定量ボンブ (Decarf : 東洋科学産業製)を用いて導入し反 応を行なった。

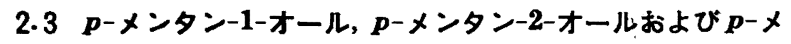
ンタン-7-オールの合成単踓

〔2〕の反応油（実匼番号 4,11 g) から未反応部を留去した油 分 $8 \mathrm{~g}$ を常法のようにエーテル溶媒を用いて， $\mathrm{LiAlH}_{4}$ による還 元を行なったのちステンレススチール製オートクレーブ中にと ク, 油分に対して $10 \mathrm{wt} \%$ の $\mathrm{Pd} / \mathrm{C}(5 \%)$ を添加し, 内温 60〜 $80^{\circ} \mathrm{C}$, 水素生 $5 \mathrm{~kg} / \mathrm{cm}^{2}$ でかきぜた。そののち, 常法のよらに 処理したのち減圧下に蒸留 (bp $89 \sim 94^{\circ} \mathrm{C} / 10 \mathrm{mmHg}$ ) し, pーメン タン-1-オールと p-メンタン-2-オールの混合油分 $6.7 \mathrm{~g}$ (収率 61\%) を得た。また，〔3]の反応油（実験番号 1,12 g）につい ても〔2]と同様な条件下で，未反応油を留去した油分 $10 \mathrm{~g}$ を $\mathrm{LiAlH}_{4}$ 昰元後，水素添加することにより，pーメンタンー7-オール と p-メンタン-2-オールの混合油分 (bp $92 \sim 98^{\circ} \mathrm{C} / 10 \mathrm{mmHg}$ ) $7.6 \mathrm{~g}$ (取事 $63 \%$ ) を得た。

\section{4 分析方法}

[1]〜[5]から得られる反応油の転化率扰よび反応生成物の 定量江楖本製 G-180 T 型 GLC [PEG 6000 10\%, $\phi 3 \mathrm{~mm} \times$ $2.25 \mathrm{~m}$ (glass), カラム温度; $180^{\circ} \mathrm{C}$, キャリヤーガス, $\mathrm{H}_{2}(1.0$ $\left.\left.\mathrm{kg} / \mathrm{cm}^{2}\right)\right]$ にった。反応生成物は必要に応して蒸留の反復ある いは PEG-20 M を固定相とする分取 GLC [ $\phi 3 \mathrm{~mm} \times 2.25 \mathrm{~m}$ (glass), カラム温度; $170^{\circ} \mathrm{C}$, キャリヤーガス; $\left.\mathrm{H}_{2}\left(0.8 \mathrm{~kg} / \mathrm{cm}^{2}\right)\right]$ により採取し, 構造の確認は既知慓品 ${ }^{15116)}$ とのIR (日本分光工業 製：IRA-2 型), NMR（日本電子株式会社製：JNM-MH-100） および GC-MS（日本電子株式会社製：JMSD-300）スペクトル により比較同定した。

\section{3 結果むよひ考察}

既報"1により調製したそれぞれのモノテルペンオキシドく1]〜 [5]について硝酸塩系溶融塩（反応温度 $375 \sim 465^{\circ} \mathrm{C}$ の籁囲）お

12) Y.R. Naves, A. V. Grampoloff, Bull. Soc. Chim. Fr., 1960, 37.

13）奥田 治, “香料化学総篭 $[\mathrm{II}] ”$, 広川書店（1972）p. 700 .

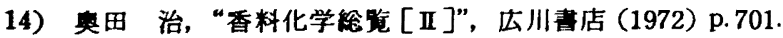

15）湯川泰秀, 尹東 做監, “Spectral Atlas of Terpenes and the Related Compounds", 広川書店 (1973) p. 62, 136, 178.

16) E. E. Royals, L. L. Harrell, Jr., J. Am. Chem. Soc., 77, 3405(1955).

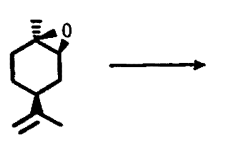

[1]

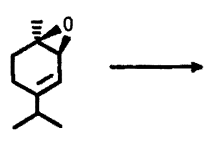

[2]

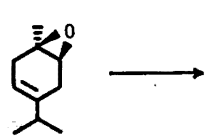

[3]<smiles>C=C(C)C1CCC(=O)C1</smiles>

[6]

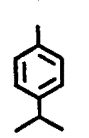

[10]

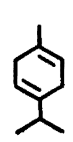

[14]<smiles>C=C(C)[C@H]1CC[C@@H](C)C(=O)N1</smiles>

[7]

[11]<smiles>CC(C)C1CCC(C=O)CC1</smiles>

[15]<smiles>CC(C)C1=CC(C)(O)CC1</smiles><smiles>C=C(C)[C@H]1CC[C@@H](C)C(=O)C1</smiles>

[8]<smiles>CC(C)C1=C[C@H](O)CC[C@H]1C</smiles>

[12]

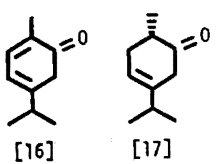

[16] [17]<smiles>CC(C)C1=CC(=O)C(C)CC1</smiles>

[9]<smiles>Cc1ccc(C(C)C)cc1O</smiles>

[13]
Fig. 1 The reaction products from [1], [2] and [3]
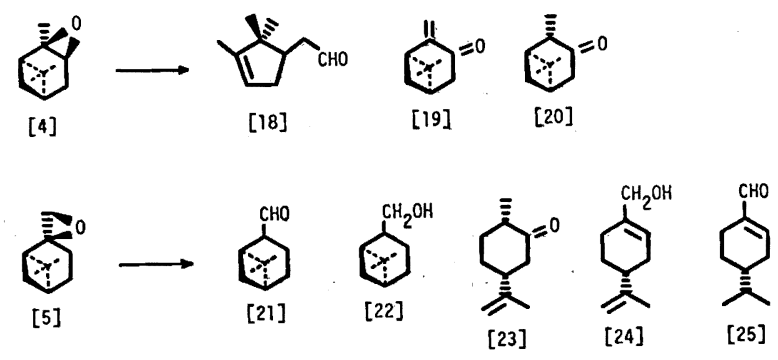

Fig. 2 The reaction products from [4] and [5]

よび塩化物系溶融塩（反応温度 $190 \sim 410^{\circ} \mathrm{C}$ の範囲）に吹き込ん で熱分解反応を行なった。それぞれの反応条件を表 1〜 5 に示 す。

3.1 trans-リモネン 1,2-オキシド〔1〕の熱分解反応

〔1]の熱分解反応では, 電気伝導性が小さく，しかも分子性無 機溶融塩の一つと考えられる塩化物系溶融塩中に打いてのみ反応 が進行した。反応条件としては反応温度が $250 \sim 415^{\circ} \mathrm{C}$ の範丑に おいて 4 種の成分 [6]〜 [9]が認められた。すなわち, 反応温 度 $250 \sim 340^{\circ} \mathrm{C}$ (実験番号 $1 \sim 4$ ) の籁围においてはアルカリ金属 あるいはアルカリ土類金属のハロゲン化物に属し，イオン性をむ つと考えられる塩化ナトリウムを含有する塩素塩系溶融塩では溶 融塩が触媒的な働きを示し, 反応の促進が認められ， $\mathrm{C}_{1}$-位侧の エーテル結合の切断が優先してネオジヒドロカルボン〔7〕とイ ソジヒドロカルボン〔8]の 2 成分の合計が生成物中 $90 \%$ 以上 を占めた。また，とくに実験番号 3 の条件では〔7]と〔8]の 2 成分のみが得られる条件も見いだすことができた。そのほか, 少量成分として従来, 著者らが行なった〔3]の熱分解反応 ${ }^{17)}$ 同様な反応形態をとり二重結合の分子内転位によって生じると考 えられるカルベノン〔9]の生成が反応温度の上昇とともに增加 する傾向が認められた。

\subsection{1,2-エポキシ-3-p-メンテン〔2〕の熱分解反応}

[2]の熱分解反応では硝酸塩系溶融塩中においてのみ反応が 進行した。すなわち, 反応温度 $350 \sim 450^{\circ} \mathrm{C}$, 内压 $20 \sim 60 \mathrm{mmHg}$ の条件において 5 種の成分 [ 9$]$ ～[13]を確認することができた。 表 2 に示したように反応温度の上昇にともない転化率が向上し,

17）野村正人, 藤原義人, 油化学, 35，454(1986). 
Table 1 Conditions for thermal decomposition of [ 1$]$ and the product compositions

\begin{tabular}{|c|c|c|c|c|c|c|c|c|c|}
\hline \multirow{2}{*}{ Run } & \multirow{2}{*}{ Fused salt } & \multirow{2}{*}{$\begin{array}{l}\text { Temp } \\
\left({ }^{\circ} \mathrm{C}\right)\end{array}$} & \multirow{2}{*}{$\begin{array}{l}\text { Press } \\
(\mathrm{mmHg})\end{array}$} & \multirow{2}{*}{$\underset{(\mathrm{m} l / \mathrm{h})}{\text { Flux }}$} & \multirow{2}{*}{$\begin{array}{l}\text { Conv } \\
(\%)\end{array}$} & \multicolumn{4}{|c|}{ Product composition (\%) } \\
\hline & & & & & & {$[6]$} & {$[7]$} & {$[8]$} & {$[9]$} \\
\hline 1 & Chloride & 250 & 40 & 10 & 63 & $t$ & 38 & 57 & 5 \\
\hline 2 & Chloride & 280 & 50 & 10 & 72 & $t$ & 34 & 58 & 3 \\
\hline 3 & Chloride & 310 & 35 & 10 & 75 & $t$ & 35 & 65 & $\mathbf{t}$ \\
\hline 4 & Chloride & 340 & 35 & 10 & 75 & 2 & 34 & 62 & 2 \\
\hline 5 & Chloride & 410 & 35 & 10 & 87 & 32 & 30 & 20 & 18 \\
\hline
\end{tabular}

Table 2 Conditions for thermal decomposition of [2] and the product compositions

\begin{tabular}{cccccccccccc} 
Run & Fused salt & $\begin{array}{c}\text { Temp } \\
\left({ }^{\circ} \mathrm{C}\right)\end{array}$ & $\begin{array}{c}\text { Press } \\
(\mathrm{mmHg})\end{array}$ & $\begin{array}{c}F l u x \\
(\mathrm{~m} l / \mathrm{h})\end{array}$ & $\begin{array}{c}\text { Conv. } \\
(\%)\end{array}$ & \multicolumn{4}{c}{ Product composition $(\%)$} \\
\hline 1 & Nitrate & 350 & 45 & 15 & 55 & 18 & 12 & 22 & 35 & 9 & 4 \\
2 & Nitrate & 380 & 40 & 15 & 60 & 20 & 10 & 25 & 41 & 2 & 2 \\
3. & Nitrate & 400 & 60 & 15 & 64 & 12 & 2 & 38 & 44 & 2 & 2 \\
4 & Nitrate & 420 & 20 & 15 & 79 & 10 & 6 & 30 & 40 & 4 & 10 \\
5 & Nitrate & 450 & 50 & 15 & 84 & 16 & 14 & 18 & 19 & 7 & 14
\end{tabular}

a) Others consisted of several components.

同時にカルベノール〔12〕の生成割合が増加する傾向が認められ た。実験番号 3 の条件ではエーテル結合の開裂が $\mathrm{C}_{1}$-位侧と $\mathrm{C}_{2^{-}}$ 位側へほぼ同程度起こりテルピネンー1-オール〔11]と〔12]の 2 成分が生成物中 $80 \%$ 以上を占め, その割合はおおよそ $1: 1$ で あることもわかった。また，反応温度の上昇にともない，転化率 は上昇するが，生成物の選択性が低下する結果が認められた。実 験番号 3 の反応油についてェーテル中 $\mathrm{LiAlH}_{4}$ 還元を行なったの ち， Pd/C (5\%) を触媒とする水素添加により調合べースとして 要求度の高い $p$-メンタノール類である $p$-メンタン-1-オールと p-メンタン-2-オールに誘導し, その反応油の GLC 組成比が $2: 3$ の割合の油分に集約することができた。

\section{3 . 3 1,2-エボキシ-4-p-メンテン〔3]の熱分解反応}

[3]の熱分解反応に怙いても〔1]と同様, 分子性をるつ塩化 物亲溶融塩中に扎いてのみ反応が進行した。すなわち, 反応温度 $200 \sim 300^{\circ} \mathrm{C}$, 内压 $15 \sim 30 \mathrm{mmHg}$ の符囲の条件において 5 種の成 分 [10], [14]〜 [17] を確認することができた。表 3 に示した実験 番号 1 の条件では反応油の転化率が $75 \%$ 以上で, しかも $\mathrm{C}_{1}$-位 側のエーテル結合の開裂が雾先的に起こり 4-p-メンテン-2-オン 〔17〕が生成物中 $80 \%$ 近い生成比を占めることがわかった。 た，反応温度が上昇するにしたがって〔17〕の生成割合が娍少 し，炭化水糸である〔14〕の生成比が増加する傾向す認められ た。そのほか，少量成分としては 4-p-メンテン-7-フール〔15]
と 5-イソプロピル-2-メチル-2,4-シクロへキサジェン-1-オン

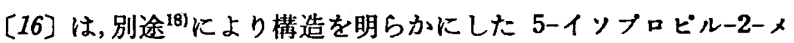
チル-2,4-シクロへキサジェンー1-オールを酸化することにより得 られるケトン体の IR, NMR スベクトルと比較同定されることか らその生成を確認することができた。また，これら生成物を炭化 水素部とケトン部に分別したのち，そのケトン部についてェーテ ル中 $\mathrm{LiAlH}_{4}$ 還元を行なったのち， Pd/C (5\%) を触媒とする水 素添加を行なうことにより，香料基材としてる利用できる ンタン-7-オールと $p$-メンタン-2-オールの 2 成分に集約するこ とができた。

\subsection{2-ビネンオキシド[4]の熱分解反忍}

塩化物系溶融塩と硝酸塩系溶融塩を用いて熱分解反応を行なっ た場合，いずれも 3 種の成分 [18]〜[20]が認められた。しか し, 溶融塩の種類および反応温度の相違により主成分 [18]の選 択性に大きな相違が認められた。すなわち，塩化亜鉛を主成分と する塩化物系溶融塩では塩化重鉛は比較的低温 $\left(400^{\circ} \mathrm{C}\right.$ 以下) の 状態において分子性を示す塩とされており，著者らが行なった 200 280 $\mathrm{C}$ の温度範用において温度の影䈏が溶虽塩の分子性に も影響をおよぽすことが考えられる。このことは表4に示した絬 果からも触媒作用としての溶骶塩が認められ、反応油の䢂化京向 上が認められるとともに生成物中 $\alpha$-カンホレンフルデヒド [18] とピノカルポン [19]の 2 成分が $90 \%$ 以上を占めた。とくに表

Table 3 Conditions for thermal decomposition of [3] and the product compositions

\begin{tabular}{ccccccccccccc} 
Run & Fused salt & $\begin{array}{c}\text { Temp } \\
\left({ }^{\circ} \mathrm{C}\right)\end{array}$ & $\begin{array}{c}\text { Press } \\
(\mathrm{mmHg})\end{array}$ & $\begin{array}{c}\text { Flux } \\
(\mathrm{m} l / \mathrm{h})\end{array}$ & $\begin{array}{c}\text { Conv. } \\
(\%)\end{array}$ & \multicolumn{4}{c}{ Product composition $(\%)$} \\
\hline 1 & Chloride & 200 & 15 & 50 & 76 & 3 & 2 & 3 & 6 & 77 & 9 \\
2 & Chloride & 250 & 15 & 50 & 91 & 12 & 9 & 10 & 8 & 59 & 2 \\
3 & Chloride & 280 & 15 & 40 & 87 & 23 & 10 & 12 & 12 & 38 & 5 \\
4 & Chloride & 280 & 30 & 50 & 92 & 27 & 12 & 14 & 15 & 32 & $t$ \\
5 & Chloride & 300 & 15 & 50 & 96 & 32 & 10 & 12 & 15 & 21 & 10
\end{tabular}

a) Others consisted of sevral components.

18）野村正人，藤原義人，日化， 1980，779. 
日 本化学 会誌 1988 No.3

Table 4 Conditions for thermal decomposition of [4] and the product compositions

\begin{tabular}{cccccccccc} 
Run & Fused salt & $\begin{array}{c}\text { Temp } \\
\left({ }^{\circ} \mathrm{C}\right)\end{array}$ & $\begin{array}{c}\text { Press } \\
(\mathrm{mmH})\end{array}$ & $\begin{array}{c}\text { Flux } \\
(\mathrm{m} l / \mathrm{h})\end{array}$ & $\begin{array}{c}\text { Conv. } \\
(\%)\end{array}$ & \multicolumn{3}{c}{ Product composition (\%) } \\
\hline 1 & Chloride & 200 & 15 & 10 & 80 & 61 & 36 & 3 & $\mathrm{t}$ \\
2 & Chloride & 250 & 40 & 10 & 86 & 51 & 44 & 5 & $\mathrm{t}$ \\
3 & Chloride & 280 & 35 & 10 & 88 & 46 & 44 & 4 & 6 \\
4 & Nitrate & 400 & 15 & 10 & 42 & 40 & 31 & 15 & 14 \\
5 & Nitrate & 430 & 45 & 10 & 51 & 32 & 27 & 14 & 27 \\
6 & Nitrate & 465 & 40 & 10 & 64 & 24 & 20 & 11 & 45
\end{tabular}

a) Others consisted of several components.

Table 5 Conditions for thermal decomposition of [5] and the product compositions

\begin{tabular}{|c|c|c|c|c|c|c|c|c|c|c|c|}
\hline \multirow{2}{*}{ Run } & \multirow{2}{*}{ Fused salt } & \multirow{2}{*}{$\begin{array}{l}\text { Temp } \\
\left({ }^{\circ} \mathrm{C}\right)\end{array}$} & \multirow{2}{*}{$\underset{(\mathrm{mmHg})}{\text { Press }}$} & \multirow{2}{*}{$\underset{(\mathrm{ml} / \mathrm{h})}{\text { Flux }}$} & \multirow{2}{*}{$\begin{array}{c}\text { Conv. } \\
(\%)\end{array}$} & \multicolumn{6}{|c|}{ Product composition (\%) } \\
\hline & & & & & & [21] & [22] & [23] & [24] & [25] & Others ${ }^{a}$ \\
\hline 1 & Chloride & 270 & 75 & 10 & 90 & 73 & 20 & 6 & 1 & $t$ & $t$ \\
\hline 2 & Chloride & 300 & 25 & 10 & 89 & 75 & 22 & 2 & 1 & - & - \\
\hline 3 & Chloride & 360 & 90 & 10 & 90 & 72 & 11 & 8 & 9 & $\mathrm{t}$ & $\mathrm{t}$ \\
\hline 4 & Nitrate & 375 & 750 & 10 & 52 & 72 & 5 & 6 & 5 & 4 & 8 \\
\hline $\mathbf{5}$ & Nitrate & 390 & 45 & 10 & 57 & 63 & 8 & 8 & 9 & 2 & 10 \\
\hline 6 & Nitrate & 415 & 30 & 10 & 64 & 61 & 3 & 6 & 3 & 3 & 24 \\
\hline
\end{tabular}

a) Others consisted of several components.

4 に示した実験番号 1 では $\mathrm{C}_{1}$-位の $\mathrm{C}_{(1)}-\mathrm{C}_{(6)}$ 結合が $\mathrm{C}_{(2)}-\mathrm{C}_{(6)}$ 結 合へ枟位し，ついで Wagner-Meerwein 転位が起こって，五員 㻴生成物である [18]が 61\% の生成比を占めた。また，反応温 度を高くすると五員理生成物〔18]の生成比が減少する一方， $\mathrm{C}_{1}$-位㑡のエーテル結合の開裂により生成する〔20]の生成比が 增加する㑯向が㒛められた。硝酸塩系溶融塩では溶融塩を形成し ている化合物の組成から熱媒体としての効果のみが存在すること が考えられ, 反応温度が高い $\left(400^{\circ} \mathrm{C}\right.$ 以上) ため, 生成物の選択 性がそこなわれ、しかる構造未確認の生成物が增加する個向が認 められた。

\section{$3.52(10)$-ビネンオキシド[5]の熱分解反応}

2 種の無機混合溶融塩中での熱分解反応ではいずれる $\mathrm{C}_{2}$-位側 のエーテル結合の切断が優先し, 少量成分を含む 5 種の成分 [21] 〜[25]を確詻した。塩化物系溶融塩では高温になると塩化亜鉛 は㙁化ナトリゥム，塩化カリウムのイオン性溶融塩と同しように イオン的な篗造へ移行することが考えられ，270〜360 $\mathrm{C}$ の温度 渻囲において，生成物に選択性を見いだすことができた。すなわ ち、表 5 に示したよらに反応油の転化率がよく，生成物中ミルタ ナール〔21]がいずれる $70 \%$ 以上の生成比を占めた。また，

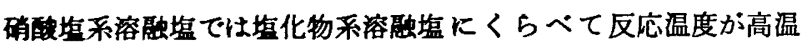
$\left(100^{\circ} \mathrm{C}\right.$ 以上む高い) Kもかかわらず，反応性（転化率か： $60 \%$ 前 後）に乏しく，しかも，生成物の選択性が久け，わずかながら実
験番号 5 に示した条件において〔21]が $72 \%$ の生成比を占める 程度である。また，いずれの溶融塩においても反応温度を上昇 $\left(400 \longrightarrow 500^{\circ} \mathrm{C}\right)$ させると, ピナン骨格の開裂が生じて, $p$-メン テン骨格を有するジヒドロカルボン〔23], ペリリルアルコール 〔24]およびジヒドロペリリルアルデヒド〔25]の生成割合が増加 する傾向が認められた。

以上, 今回著者らが行なった 2 種の無機混合溶融塩中での [1] 〜 [5]の熱分解反応では, 溶融塩の種類や反応温度によって, 収率扰よび生成物の生成比にいちじるしい相違が生じることを認 めた。すなわち，同じ p-メンテン骨格を有している〔1]，〔2] および [3]の熱分解反応では塩化物系溶融塩中で [ 1]と [ 3] の熱分解反応が起こって $200 \sim 300^{\circ} \mathrm{C}$ の温度範围で [7]，〔8]お よび〔17〕の生成に選択性を見いたすことができた。一方，ピナ ン骨格を有し，反応性に富む〔4〕および〔5〕の熱分解反応で は, いずれる塩化物系溶融塩中での熱分解反応の方が，硝酸塩系 溶融塩中での熱分解反応にくらべて低温領域 $\left(100 \sim 200^{\circ} \mathrm{C}\right.$ の差) で反応が起こり，〔18],〔19]纺よび〔21〕の生成に選択性を見い だすことができた。

そのほか, 無機混合溶融塩は高温で熱安定性がよく反応生成物 との分離が簡単で，しかも副生成物による溶融塩の劣化がなく， つねに塩が新鮮にたもたれているなどの利点を備えていることが 判明した。 


\section{Thermal Decomposition Reaction of Monocyclic and Bicyclic Monoterpene Oxides in Mixed Fused Salts ${ }^{\dagger}$ \\ Masato Nomura* and Yoshihito Fujihara \\ Department of Industrial Chemistry, Faculty of Engineering, Kinki University ; Hirokoshingai, Kure-shi 737-01 Japan}

Thermal decomposition reactions of trans-limonene-1,2-oxide [ 1$], 1,2$-epoxy-3-p-menthene [2], 1,2-epoxy-4-p-menthene [3], 2-pinene oxide [4] and 2(10)-pinene oxide [5] were carried out in $\mathrm{ZnCl}_{2} / \mathrm{KCl} / \mathrm{NaCl}$ fused salts (chloride fused salts) or $\mathrm{NaNO}_{2} / \mathrm{NaNO}_{3} / \mathrm{KNO}_{8}$ fused salts (nitrate fused salts). In the chloride fused salts, neo- and isodihydrocarvone [7] and [8] were obtained as the two main products from [ 1$]$. Under particular conditions, the ratio of [7] to [8] was $2: 3$. $\alpha$-Campholenaldehyde [18] and pinocarvone [19] were obtained from [4] as the two main products, amounting to more than $97 \%$ of the thermal decomposition products. Myrtanal [21] was obtained as the principal component from [5] with the $70 \%$ selectivity.

$\dagger$ Studies on the Thermal Decomposition of Terpenes in Mixed Fused Salts. u. 